\title{
CLAIMS OF TERRITORIAL JURISDICTION IN WIDE BAYS.
}

By a recent decision of the High Court of Justiciary in Edinburgh $^{1}$ (the Supreme Criminal Court of Scotland), a clause in an Imperial Statute ${ }^{2}$ has been interpreted as an affirmation by the British Parliament of territorial jurisdiction, at least for the purpose of fishery regulation, over an area of water on the northeast coast of Scotland more than two thousand geographical square miles in extent, and bounded by an imaginary line drawn between headlands eighty miles apart. Correct as the decision no doubt was, it arrested the attention of those interested in international law by its attribution to the British Parliament of a reaffirmaion of the theory of the "King's Chambers," which, though at one time supported by Kent, Wheaton and Phillimore, has found but little support from more recent English authorities like $\mathrm{Hall}^{3}$ and Westlake, ${ }^{4}$ and has been regarded by continental writers as having been abandoned as a general principle by Great Britain and the United States in the second half of the nineteenth century.5 The theory itself, which dates from the time of John Selden, was a claim of "rights of property and exclusive jurisdiction" over tracts of water along the coast of England enclosed by lines drawn from headland to headland, irrespective of the distance between them. It originated, says Selden, in I604, when, during the war between Spain and the United Provinces, in which England was neutral, the belligerents did not refrain from carrying on hostilities even in English waters. To prevent their incursions, James I., by ordinance of March 2nd, I604, caused the limits of these waters to be fixed, and appointed experts to describe the parts of the sea adjoining his kingdom in which the belligerents should enjoy the royal protection. These were also designated upon a map (which is reproduced in Mare Clausum [1635

I. Mortensen v. Petcrs (July 20th, I906), Scots Law Times, xiv., p. 227. The case has not yet appeared in the Court of Session Reports.

2. Herring Fisheries (Scotland) Act, I889.

3. Hall, International Lazv, 5th edition, p. 156.

4. Westlake, International Law, i., p. I88.

5. Nys, Droit Int., i., p. 447.

6. Selden, Mare Clausum seu de Dominio Maris (1635), lib. ii., cap. ii., pp. 236 , et seq. 
ed.], p. 239) by lines joining the extreme promontories, and to the space of water included thereby was given the name King's Chambers, regice camere or chambres royales, "to show," says Selden, "that the King was master there."

It is this principle of determining the bays in which a littoral State may exercise jurisdiction that appears to have been revived three hundred years later in argument before a Scots Court, which indeed proved itself not averse from using it to justify the claim which it was constrained to hold that Parliament had made.

It is only fair to mention that the clause containing this claim is an isolated clause in an Act dealing with the regulation of herring fisheries, but it relates to a portion of the sea which Great Britain, by signing the North Sea Convention of 1882 , had already agreed, perhaps for another purpose, to treat as high seas forming the German Ocean. Moreover, the claim is inconsistent with a provision in the subsequent Herring Fishery Act of 1895 , setting forth the conditions under which the Fishery Board of Scotland may make regulations for herring fishery in waters up to thirteen miles distant from the coasts of Scotland. These points will afterwards be set forth in detail. Meanwhile I desire to make some mention of the way in which wide bays are treated by individual States and by international treaties with reference to territorial rights in them.

Of late years considerable attention has been given by International lawyers to questions concerning territorial waters, not merely with regard to their seaward limit but also to the nature of the rights possessed in them by the states whose coasts they bathe.? But the discussion passes over the problem of delimiting the extent of wide bays because it relates mainly to the maritime belt which extends into the open sea and is distinguished from proprietary waters in which the littoral state has full rights of sovereignty. These proprietary waters it is generally stated include ports, harbors, roadsteads, estuaries, bays and gulfs.

7. See "Territorial Waters; 'Questionnaire' Replies and Report." Extracted from the I5th Annual Report of the Association for the reform and codification of the Law of Nations; London, 1893. The Report contains the replies received as to the existing law of Canada, Sweden and Norway, Germany, Italy, Spain, and Austria, in answer to the "Questionnaire" drawn up and circulated by an infuential and representative Committee on Territorial Waters appointed by this Association in 1887 . In an appendix is contained the proposals with motifs, which Mr. (now Sir Thomas) Barclay submitted for adoption to the Institute of International Law at its Geneva meeting in 1892. Hereinafter referred to as Report. Cf. also Annuaire de l'Institut de Dr. Int. XII and XIII; Godey, "La Mer Côtic̀re," Paris, I8g6; Schücking, Das Kïstenmur im int. Recht, Göttingen, I897; and de Lapradelle, Le Droit de l'Etat sur La Mer Territoriale, Paris, 1898. 
The distinction is not of recent date for it was taken by Cockburn, C. J., in the great case of Regina v. Keyn, 1876, R. 2 Ex. Div. 63 at p. 162 (which led to the passing of the British Territorial Waters Jurisdiction Act of 1878). He there pointed out that by the ancient common law of England a bay, gulf, or estuary inter fauces terrae was considered part of the realm of England so that an offence committed in parts of the sea so circumstanced could be dealt with by the common law because they were considered to be within the body of the adjoining county or counties from which the jury is to ascertain the fact required to be drawn. The distinction has been followed in the Scots Court, ${ }^{8}$ and it is well recognized by continental writers and by the Institute of International Law. Thus in Germany, to take only one instance, v. Liszt ${ }^{9}$ terms such waters Eigengewässer in opposition to Küstengewässer or coastal waters in which, for his part, he concedes only a limited right of sovereignty to the littoral state. The Institute in Resolutions ${ }^{10}$ adopted subsequently to those dealing with territorial waters ${ }^{11}$ (to which we shall afterwards refer) said in Section 2:

Les dits ports, havres, anses, rades et baies (c. à. d. baies et havres qui pcuvent être assimilés à ces anses et rades), non seulement sont placés sous un droit de souveraineté des Etats dont ils bordent le territoire mais encore font partie du territoire de ces Etats.

When, however, we inquire if there is any limit to the extent of the bays which are thus considered to form part of the territory of the littoral state we find no unanimity as to the rule of measurement. The continental writers incline to state the rule without due regard to state practice or with too much regard to international conventions which are not of universal application, v. Liszt, for example, says that the line of demarcation between territorial and coastal waters in bays is usually fixed by an imaginary line drawn from shore to shore at a point where the center of it is within range

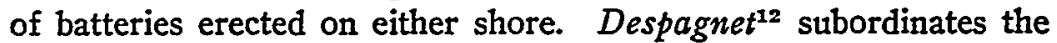
very existence of the limited right of sovereignty which he also concedes, to the condition that the littoral state can exercise complete command over the bay or gulf in its whole extent, which therefore,

8. Lord Advocate v. Trustees of the Clyde Navigation, I89r, Ig Court of Session Reports (4th series), p. I74, per Lord Kyllachy (Judge of First Instance).

9. Das Völkerrecht, 3rd ed. (I904) p. 85.

10. Projet de réglement sur le régime légal des navires et de leurs equipages dans les ports étrangers (1897), XVI Annuaire, p. 23I.

II. Définition et régime de la mer territoriale (I894), XIII Annuaire, p. 328.

12. Cours de Dr. Int. (I905) Section 406. 
he says, ought not to exceed double the range of cannon shot from the shore. Some English writers on the other hand discard all artificial limitations depending on the range of cannon shot and rest their claim on the proximity of headlands enclosing the waters in question. Thus, according to Wheaton, ${ }^{13}$ the maritime territory of every state extends to the ports, harbors, bays, mouths of rivers and adjacent parts of the sea enclosed by headlands belonging to the same state. Phillimore ${ }^{14}$ (who upholds Britain's ancient claim to the King's Chambers) states the rule in words containing only slight alterations for the sake of clearness. But this rule is not less objectionable than that based on artificial limits. It suffers from vagueness, and gives no criterion of the distance between the "headlands" or of the meaning of "enclosed." The headlands might indeed be as far apart as the South Cape of Florida and the mouths of the Mississippi between which Chancellor Kent proposed to draw a line to mark off the territorial rights of the United States in the Gulf of Mexico. Hall15 who is much more cautious puts his finger on the true criterion, without indeed being able to give it precision, when he says that there is nothing in the conditions of valid maritime occupation to prevent the establishment of a claim to basins of considerable area if approached by narrow entrances such as the Zuyder Sea or to large gulfs which, in proportion to the width of their mouths, run deeply into the land, even when so large as Delaware Bay or still more to small bays such as that of Cancale.

The physical configuration and economic importance of bays vary so much that it is perhaps hopeless to expect greater precision in a rule which shall be applicable to them all, but it is well to insist on the element to which Hall refers. He puts in another way the words intra fauces with which Lord Cockburn qualified the bays that the ancient common law reckoned as part of the realm, and which Wheaton and Phillimore had in view when they spoke of bays being enclosed by headlands. As Dana said before the Halifax Fishery Commissioners," "Names will not help us. The Bay of Bengal is not national property, it is not the King's Chambers; nor is the Bay of Biscay, nor the Gulf of St. Lawrence. An inlet of the sea may be called a bay and it may be two miles wide at its entrance, or it may be called a bay and it may take a month's passage in an old-fashioned sailing-vessel to sail from one headland to the other."

13. Ed. Atlay (1904) p. 275.

I4. I. Int. Law, 284

15. Int. Law, 5th ed.

I6. (1877) Appointed under the Treaty of Washington, I87I, quoted in I Phillimore, 288. 
The element of configuration to which Hall refers is important because it implies that the littoral state can command the entrance by armed force from the shore. It would, however, be wrong to assume that the width of the entrance must not exceed twice the three-mile limit because that limit relates to the extent of the maritime belt from which proprietary waters such as bays are distinguished, and because the entrance to the bay takes the place of low-water mark which is the usual starting point for reckoning the limit. Moreover it is impossible to say that the three-mile limit is a rule of international law binding on all states at all times and for all purposes. Originating as a working rule based on the principle of Bynkershoek Potestatem terrae finiri ubi finitur armorum vis (that the power of a state extends so far as it can reach), it has been rendered by the increase in the range of modern cannon quite inadequate for the protection of a littoral state. ${ }^{17}$ No state uniformly adopts it as a maximum for all purposes. The Territorial Waters Jurisdiction Act, 1878 , for instance, proceeds on a preamble which carefully abstains from laying down any general limit, ${ }^{18}$ and solely for the purpose of criminal jurisdiction over vessels in such seas defines territorial waters to be within one marine league from low-water mark, and although the limit is commonly adopted for neutrality purposes, the British Foreign Enlistment Act of $1870^{19}$ simply refers to territorial waters without defining them.

17. As early as I864, Mr. Seward, on behalf of the United States, suggested to the British Legation at Washington that in view of the increased range of projectiles the limit for neutrality purposes should be extended from three miles to five. On the assumption that the neutral littoral zone within the existing limits was entitled to the same protection as neutral soil, Mr. Seward further suggested that belligerent war vessels should be prohibited from opening fire within three miles of it. If the three-mile limit were retained, and the increased range of cannon taken at five miles, he proposed that the prohibition should be directed against firing within eight miles of the neutral coast. Cf. Bluntschli, Droit Int. Codifié, tr. Lardy, 3rd ed. p. I89. Fuller in Nys, Droit Int. L. p. 512.

18. The rightful jurisdiction of $H$. $M$., her heirs and successors extends and has always extended over the open seas adjacent to the coasts of the United Kingdom and of all other parts of H. M. dominions to such distance as is necessary for the defence and security of such dominions.

19. The circular of 1oth February, 1904, issued by Lord Lansdowne on behalf of the Foreign Office under this act and addressed to the Lords Commissioners of the Admiralty with regard to the rules to be observed to maintain the neutrality of Great Britain during the Russo-Japanese war refers to "British ports, roadsteads, or adjaccnt watcrs subject to the territorial jurisdiction of the British Crown." 
The Sea Fisheries Act, 1883 ( 46 and 47 Vic. c. 22 ), afterwards referred to, which carries into effect as regards Great Britain the provisions of the North Sea Convention of 1882, also abstains from giving a general definition even to the exclusive fishery limits of Great Britain.

The preamble to the Paris Resolutions ${ }^{20}$ adopted by the Institute of International Law in 1894 proceeds also on the insufficiency of the three-mile limit for the protection of fishery rights. To meet the new conditions, the. Institute recommended de lege ferenda a distance of six geographical miles, measured from low-water mark, for adoption as a general rule, allowing (Art. 4) a riparian State in time of war to fix by its declaration of neutrality, or by special notification, its neutral zone beyond the six miles up the range of guns on the coast. ${ }^{21}$

For the purpose of this paper it will be sufficient to quote Articles $I$ to 3 of the Resolutions which run as follows:-

“I. L'état a uri droit de souveraineté sur une zone de la mer qui baigne la côte, sauf le droit de passage inoffensif réservé à l'article 5 .

"2. La mer territoriale s'étend à six milles marins (60 au degré de latitude) de la laisse de basse marée sur toute l'étendue des côtes.

"3. Pour les baies, la mer territoriale suit les sinuosités de la côte, sauf qu'elle est mesurée à partir d'une ligne droite tirée en travers de la baie dans la partie la plus rapprochée de l'ouverture vers la mer où l'écart entre les deux côtes de la baie est de douze

20. Considérant qu'il n'y a pas de raison pour confondre en une seule zone la distance nécessaire pour l'exercice de la souveraineté et pour la protection de la pêche littorale et celle qui est pour garantir la neutralité des nonbelligérants en temps de guerre; que la distance la plus ordinairement adoptée de trois milles de la laisse de basse marée a été reconnue insuffisante pour la protection de la pêche littorale; que cette distance ne correspond pas non plus à la portée réelle des canons placés sur la côte."

21. After the publication of the Paris Resolutions the Dutch Government, in December, 1895, addressed a Collective Note to the Powers, inviting them to an international agreement based on these resolutions, which would have had the effect of making the second neutrality zone proposed by the Institute and extending to twelve miles from low-water mark obligatory on all the Powers. The increased obligations which this project would have imposed upon neutrals in maintaining respect for their neutrality led to the rejection of the proposal. It was felt, moreover, that the adoption of this limit might lead to violations of neutral territory on the part of belligerents in consequence of the limitation of the theater of marine hostilities. Cf. Godey, La Mer Côtière, I8g6, p. 24; Nys, Int. Law, i., p. 513; Schücking, Die Verwendung von Minen im Seekrieg; Zeitschrift für Int. Priv. . Off. Recht. (1906), xiv., 121, at 138 . 
milles marins de largeur à moins qu'un usage continu et séculaire n'ait consacré une largeur plus grande."

Several well-known decisions on the territorial character of wide bays would fall under the exception, under-lined above, which the Institute was constrained to admit to its proposed rule of measurement. They were nearly all cases of true bays for the width of their entrance though greater than double the three-mile limit was much less than the extent to which they ran into the adjoining land. Thus Chesapeake Bay, a long arm of the Atlantic Ocean, running roughly north and south, and cutting into the States of Virginia and Maryland, is claimed by the United States. Measuring twelve miles in width at its entrance between Cape Charles and Cape Henry, in the State of Virginia, it is at least two hundred miles in extent, although it is probably nowhere more than twenty miles wide. The territorial character of this bay was, after mature deliberation, judicially affirmed for all purposes by the American Court of Commissioners of Alabama Claims in the case of the Alleganean, ${ }^{22}$ in which it was essential for the Court to decide whether a particular place in the bay south of the Rappahannock River, and more than four miles from any land, was, or was not, in the "high seas" within the meaning of Section 5 of Act of Congress of June $5^{\text {th, }}$ 1872, which entitled American citizens, under certain circumstances, to recover compensation from the United States for losses sustained by the'depredations of the Confederate navy in the Civil War.

Delaware Bay, fifteen miles in width at the entrance, was claimed by the Executive Government of the United States in 1793, when, at the instance of Great Britain, they compelled the restoration of the British ship Grange, which had been captured by the French in the bay, in violation of the neutrality of the United States. ${ }^{23}$ This claim, in which both Great Britain and France acquiesced, depended, according to Wharton, ${ }^{24}$ solely on "the fact that the United States are proprietors of the lands on both sides of the Delaware, from its head to its entrance to the sea." Here also we have an application of the King's Chambers theory.

Long Island Sound, between Long Island and the State of Connecticut, was held to be part of New York State, and subject to its jurisdiction. ${ }^{25}$

22. Albany Law Journal, xxxii., 484; Moore's Int. Arbit., iv., 433; id., v., 4675; Scott's Leading Cases on Int. Law, 143.

23. American State Papers, i., 73.

24. F. Wharton, $A$ Digest of the International Law of the United States, vol. i., p. 75, Section 28.

25. Mahler v. Transportation Company (1866), 35 N. Y. 352 . Quoted in Scott's Leading Cases on Int. Law, p. I53. 
On the other hand, the claim of Great Britain that the Bay of Fundy, lying between New Brunswick and Nova Scotia, was a British bay, from which United States fishermen were excluded by the Treaty between Great Britain and the United States of 1818, has been abandoned since $1845 .{ }^{28}$ This bay, which is from sixty-five to seventy-five miles wide, and from one hundred and thirty to one hundred and forty miles long, with several "bays" in its coasts, has one of its headlands in the United States (Maine), and it must be traversed for a long distance by vessels bound to Passamaquoddy Bay (lying between Maine and New Brunswick). Moreover, it contains a United States island, Little Menan, on the line between the headlands. For these reasons, Mr. Bates, the umpire to whom the claim of the owners of the United States schooner Washington (seized and confiscated for illegal fishing in the bay under the Treaty of 1818 ) had been referred, under the provisions of the Treaty of Washington, $187 \mathrm{I}$, decided that the bay must be considered as an arm of the open sea. ${ }^{2 \pi}$

The territorial character of the Bay of Conception, in Newfoundland, which runs forty miles into the land, and has an entrance twenty miles wide, was unanimously affirmed by the British Privy Council in 1877 in the case of the Direct United States Cable Company, Limited, v. The Anglo-American Telegraph Company, Limited..$^{28}$ The court here went partly on the configuration of the bay, and partly on the historical evidence of a continued claim to territorial sovereignty on the part of Great Britain.

The only case prior to Mortensen $v$. Peters, already mentioned, in which a British court has had to deal with the territorial character of a large arm of the sea in England, is Regina v. Cunningham (Bell's Crow'n Cases, 86), relating to the Bristol Channel. Here the Queen's Bench expressed the opinion that the whole of this channel between Somerset and Glamorgan is to be considered as within the counties by the shores of which its several parts are respectively bounded. It follows, therefore, that, in the opinion of the Court, the Bristol Channel so defined was subject to the territorial sovereignty of Great Britain.

The following description of the Bristol Channel is condensed from the judgment of the Irivy Council in the Direct United States Cable Company's case:-

It is an arm of the sea dividing England and Wales, into the upper end of :hich the River Severn flows. On the English side its boundary is

3c. Cf. Phillimore, Int. Law, i., p. 289.

37. Repurt of Commissions of Claims, 1853, p. 170. Quoted in Wharton, Digest, iii., Section 305, at p. 59.

28. Law Reports, Appeal Cases, ii., 394. 
formed by the counties of Somerset and Devon, and on the Welsh side by the counties of Glamorgan, Carmarthen, and Pembroke. The channel widens as it descends, and between Port Eynonhead, the lowest point in Glamorgan, and the opposite coast of Devon, is, roughly, twenty miles wide; while lower still, between Hartland Point, in Devon, and the opposite coast of Pembroke, the width is about thirty-seven and a half miles. The case did not decide what was to be regarded as the entrance to the Bristol Channel, but it is incidentally stated in the case reserved for the opinion of the court, that from Penarth Roads, where the crime was committed, to the mouth of the channel, is a distance of ninety miles. This, as the Privy Council indicate, would point to the headlands in Pembroke, and Hartland Point, in Devon, as being the fauces of that arm of the sea.

The opinion was perhaps unnecessary for the decision of the question at issue, as the court was only asked to decide whether a particular spot in Penarth Roads in the Bristol Channel, and ten miles from the coast of Somerset, on the opposite side at which three foreigners on board a foreign ship had committed a crime, was within the county of Glamorgan in Wales, the indictment having, whether necessary or not, charged the offence as having been committed in that county. After an elaborate argument the indictment was sustained, and the opinion which I have quoted was also expressed.

From the Report of the Association and other sources one is able, apart from decided cases, to give some indication of the municipal law as to bays in countries other than those already mentioned. Thus, with regard to Canada, Mr. A. R. Gordon ${ }^{29}$ says:-

"The contention of Canada has ever been that all bays are territorial waters, where both headlands forming the extremities are within the territory of the State. As declaratory of this right the Bay of Chaleur has been continuously closed to the United States fishermen since shortly after their denunciation of the Fishery Clauses of the Washington Treaty, I87I, the distance from Birch Point Lighthouse to Point Macquereau Light being sixteen miles, these two points having been selected as being easily discernible objects to define the delimiting line, though the narrowest part of the entrance is between N. Nya Point and Macquereau, and is only fourteen and a half miles. Excepting this bay, all other bays exceeding six miles in width at entrance have been, as an act of grace, opened temporarily as a fishing-ground to United States fishermen in common with our citizens."

Western Australia, says Mr. Haynes, ${ }^{30}$ gravely advances an ambiguous claim to all bays the headlands of which are "in sight

29. Report, p. I. Replies of Mr. A. R. Gordon, Canada.

30. "Territorial Waters and Ocean Fishery Rights," by T. H. Haynes; Rcport of Guildhall Conference of the Association for Reform, etc., of Int. Law, 1894, p. 107. 
of one another." The colony also claims Exmouth Gulf, twelve and a half miles across, and Shanks Bay, with passage thereto, thirteen and a half and twenty miles in width. In I889, she obtained a Pearl and Bêche-de-mer Fishing (Extra-territorial) Act, which received the Royal Assent in I890, and empowers her to apply her local Fishing Acts to British vessels engaged in pearl fishing beyond the threemile limit of the coast of the colony. The effect of the Act is to subject such vessels not only to an export duty on shells raised by them outside the said limit, but to an import duty on stores which they take on board from their own vessels, and which may never have entered the Colony. ${ }^{31}$

The German Empire, long before the North Sea Convention of I882, which stiggested the rule to France and Belgium, limited its claim of territ rial sovereignty, at least as regards exclusive fishery rights, to bay's which are not more than ten sea miles in width, reckoned from thi' extreme points of land. 'The acquiescence of Great Britain in this claim is shown by the Notification of the Board of Trade of December, I874, issued for the guidance and warning of British fishermen fishing off the coasts of the German Empire. The Notification recited that an agreement had been reached between the governments of the respective countries regarding the regulations to be observed by British fishermen, and detailed the exceptional circumstances in which such fishermen were allowed to enter these limits. $^{32}$ Germany claims also the Bay of Stettin, in the Baltic, and Jade Bay, in the North Sea (formerly the estuary of the Weser). ${ }^{33}$ The territorial character of the Frisches Haff, near Königsberg, and the Kurisches Haff, near Memel, are incontestable, since these

3r. Report, $: 97$. Notes by Mr. T. H. Haynes.

32. Herstlet, Commercial Treaties, xiv., p. 1058, altering Notification of exclusive fishery limits of North German Confederation, October, r868, given at p. 1055, ante. These limits were designated by the Imperial Government as follows:- "The tract of the sea which extends to a distance of three sea miles from the extremest limit which the ebb leaves dry of the German North Sea coast and the German islands or flats lying before them, as well as those bays and incurvations of the coast which are ten sea miles or less in breadth, reckoned from the extremest points of the land and the fiats, must be considered as under the territorial sovereignty of the German Empire." The application of this rule would apparently give to Germany the Mecklenburger Bucht, which measures ten geographical miles (15-1 degrees) between Staber Huk, on the Island of Fehmarn, and Darsser Ort, in Pomerania, and Kieler Bucht, measuring the same distance between Schaaby, in Alsen, and Markelscorfer Huk, on the Island of Fehmarn. On the other hand, the Danziger Bucht, if measured between Rixhöft and Brüsterort. appears to be thirteen and a half sea miles wide at the entrance. See Debas, Neuer Ifandatlas (1897), sheets 16 and 17 .

33. Oppenheim, Int. Law, (Ig05), i., p. 247. 
waters are practically land-locked. The estuary of the Elbe is also claimed as German. ${ }^{34}$

Norway, which possesses the most indented coast-line in Europe, has, from ancient times ${ }^{35}$ asserted for all purposes a four-mile limit to its territorial waters, which are measured, not from the mainland, but from the outermost island off the coast which is not submerged by the sea. ${ }^{36}$ It was because she was unable to obtain international recognition for this claim that she withdrew from the Hague Convention of $1882,{ }^{37}$ on the policing of the fisheries in the North Sea, and is not a signatory to the Convention to which that Conference led. ${ }^{38}$

With regard to bays, "l'on estime en général," says Kleen, 30 "que si une baie s'enfonce dans une côte, la ligne, qui constitue la limite extérieure du territorire maritime, n'a nullement besoin de suivre la côte exactement, mais qu'elle peut être tirée parallèlement à une ligne droite entre les deux pointes du continent, qui gardent l'entrée de la baie. Même loi, si les deux pointes en question sont formées par deux îles ou brisants en dehors de la côte."

The most recent Norwegian application of the same principle is found in the Royal Resolution of September 9th, I889, by which the exterior limit of the maritime territory in which fishing is exclusively reserved to Norwegian subjects, is defined with regard to the coast of Romsdal's Amt ${ }^{\mathbf{*}}$ by a line starting from a point almost due

34. See Proc. Verb. de la Conférence de la Haye, 188r. "Pêche dans la mer du Nord," Martens's Nouv. Rec. Gen., and Series, ix., p. 5Io.

35. Kleen, in the Report, mentions a Danish Decree of October I7th, I868, in which this claim is made.

36. Bestemmelser om Territorial-Graendsen, Section I. By Rescript of February 25th, 1812, it is provided that the territorial limits "shall be reckoned to the ordinary distance of a sea mile from the outermost island, or islet, which is not submerged by the sea." Quoted in Norsk Fiskeralmanak udgivet af Selskabet for de Norske Fisheriers Fremme, Bergen, 1903, p. 215. Kleen (Report, p. 20), adds: "Bien entendu sous condition que cette ille ou ce brisant ne soit pas situé plus loin de la côte qu'une lieue géographique;" but this condition does not appear in the Rescript.

37. "Le délégué de la Norvège, M. E. Bretteville, ne peut pas accepter la fixation des limites territoriales à 3 milles, surtout en ce qui concerne les baies."-Procès-verbatıx in Martens's Nouv. Rec. Gén., 3rd series, ix., p. 510.

38. Procès-verb. No. 2, 6 May, I882; Martens, ut sup., p. 554. Cf. also Annuaire, XI, I4I.

39. Report, p. I9.

40. "A line drawn at a distance of one geographical mile and parallel to a line from Storholm over Skraapen (outside Haro), Gravskjaar (outside Ona), and Kalven (the outermost of the Orksjaerne) to the outermost Jaeveleholm (outside Grip), is to be regarded as the seaward limit of the corresponding coast of Romsdal's Amt in which fishing is reserved exclusively to the population of this country."-(Quoted in Norsk Fiskeralmanak, p. 2I5; cf. Report, p. 25, n. I.) 
north of Aalesund, and running in a northeasterly direction to a point due north of Kristiansund, enclosing a considerable extent of water off the coast of Romsdal's Amt. The islands from which the line is drawn are those lying farthest out from the mainland at the points in question, and are more than twenty miles apart.

Spain claims to exercise jurisdiction over a zone extending six miles from its coasts, and this, according to Riquelme, ${ }^{41}$ has never given rise to any claim or protest on behalf of other States. ${ }^{42}$ This claim to a six-mile limit appears now to be made only for the purposes of revenue protection and fishery regulation. For all other purposes, says $\mathrm{Nys},{ }^{43}$ the three-mile limit is the general rule.

Russia-at least, for purposes of war and neutrality-claims as territorial the whole of the waters of the White Sea, whose entrance is more than sixty miles in width. Aubert ${ }^{44}$ quotes Russian Admiralty Instructions of 1893 , in which the territorial limits of this bay are given, viz., southwards of a line drawn, at a distance of three miles, between Siratoi-Noss (a headland on the northeast coast of the peninsula of Kola) and Kanina-Noss (the northwest extremity of the peninsula of Kanin). The distance between these two points is, he says, more than a degree of latitude.

Of International Conventions in which the extent of jurisdiction in wide bays is stipulated, I may again refer to the Fishery Convention between Great Britain and France of 1839.45 It was therein provided that the rights of fishing in a zone extending three miles seaward from low-water mark on the coasts of the contracting States should be exclusively reserved to the subjects of the respect-

4T. Elementos de derecho publico international, i., p. 23 (1849); quoted in the Report (p. II4). A Customs Ordinance of November I9th, I884, authorizes the exercise of Customs jurisdiction . . . "as regards the coast, from the moment when a vessel enters the jurisdictional waters of Spain, which extend to six miles, equivalent to $x$ I.III kilometres from the coast."

42. Wheaton (ed. Atlay, 1904), p. 227) refers to protests on the part of Great Britain and United States which are later in date than Riquelme's work. Thus, during the American Civil War, the Unietd States refused to recognize the six-mile limit in regard to the neutrality of Cuba (see Note, Mr. Seward to Mr. Tassara, August Ioth, I863). Wharton's Digest, i., p. I03, Section 32. In 1874, Lord Derby intimated to the Spanish Government that their pretensions would not be submitted to by Great Britain, and that any attempt to carry them out would lead to serious consequences. $U$. S. Dip. Corr., I875, p. 64I. Mr. Fish also stated, on the part of the United States Government, "We have always understood and asserted that, pursuant to public law, no nation can rightfully claim jurisdiction at sea beyond a marine league from its coasts." Wharton's Digest, i., p. I05, Section 32.

43. Nys, Droit Int. i., p. $5 \mathrm{II}$.

44. Rev. gén. de Dr. Int. Pub. I894, p. 440.

45. Hertslet., Com. Treaties, v., 86. 
ive States. With regard to bays, Section 9 provided as follows:"It is equally agreed that the distance of three miles fixed as a general limit for the exclusive right of fishing upon the coasts of the two countries shall, with respect to bays, the mouths of which do not exceed ten miles in width, be measured from a straight line drawn from headland to headland." This stipulation was repeated in Art. I of the Fishery Convention between the same countries of $1867 . .^{40}$ In the case of the Bay of Cancale, between Cape Carteret and Point Meinga, in Brittany (seventeen miles wide), an express reservation of exclusive fishing rights is stipulated for France by both Conventions.

The North Sea Convention of 1882 for the regulation of the police of fisheries in the North Sea outside territorial waters contains' a clause with reference to bays which corresponds to that in the Anglo-French Convention of 1867 , but is framed in more precise terms. ${ }^{47}$ The Convention contains a conventional delimitation of the North Sea south of the 6Ist degree of north latitude, and provides inter alia that on the west it is bounded by the east coasts of Great Britain and Ireland. After providing that the fishermen of each country shall enjoy the exclusive rights of fishing within the distance of three miles from low-water mark along the whole extent of the coasts of their respective countries, as well as of the dependent islands and banks, Article 2 of the Convention goes on to say:-

"As regards bays, the distance of three miles shall be measured from a straight line drawn across the bay, in the part nearest the entrance, at the first point where the width does not exceed ten miles.

"The present Article shall not in any way prejudice the freedom of navigation and anchorage in territorial waters accorded to fishing boats, provided they conform to the special police regulations enacted by the Powers to whom the shore belongs."

A similar provision is contained in the subsequent Convention concluded between two of the signatories, Great Britain and Denmark on 2Ist June, 1905, with reference to the fishing off the Faroe Islands and Iceland which lie north of the 6Ist degree of latitude. ${ }^{48}$

By Treaty between Spain and Portugal ${ }^{49}$ (subsequent in date to

46. Martens, Nouv. Rec. Gén., xx., 465.

47. Procés-verbaux in Parl. Papers (3238), 1882; also Martens, Nouv. Recueil Gén., and Series, IX, 505. The date of the Convention is May 6th, I882, and the signatories are Great Britain, Germany, Belgium, Denmark, France and Holland. See Martens, ut sup., 556.

48. Five Treaty Series, 1903, No. 5; Archives Diplomatiques (1903) 3ième sér. Tom. 86, Parts 5 and 6, p. I.

49. Quoted by Professor Torres Compos in the Report, p. 93. 
the North Sea Convention), as regards the police regulations of coast fisheries (reglamento de policia de la pezca costanera), signed at Madrid on October 2nd, I885, it was provided that the limits within which the general right of fishing is reserved exclusively to fishermen, subject to the respective countries (juridicciones), is six miles measured from low-water mark. For bays whose entrance does not exceed twelve miles, the six miles are measured from a straight line drawn from one side to the other. The miles referred to are geographical miles of sixty to the degree of latitude. In this treaty no addition is made, as in the North Sea Convention, to double the territorial limit at the entrance, but the ordinary limit is the six miles customarily claimed by Spain, which of course is itself double that of the North Sea Convention. The clause is exactly that recommended by the Institute's Paris Resolutions.

Several of the States which signed the North Sea Convention have expressly adopted in their domestic legislature the ten-mile limit for bays. Thus in 1888 France enacted a law ${ }^{50}$ prohibiting foreign vessels from fishing in the territorial waters of France and Algeria and in defining the limits of these waters she adopted almost textually the provisions of the Convention. It is interesting to note that this legislation applies to French waters other than those which border the North Sea of the Convention. Belgium and Holland ${ }^{51}$ have each followed the example of France in excluding foreign vessels from fishing within the exclusive fishery limits. The Belgian law of August Igth, I891, is expressly based on the stipulations of Articles 2 and 3 of the North Sea Convention of 1882 , which it embodies. For fishery purposes, therefore, the ten-mile limit is applied to Belgian bays. I have not been able to ascertain whether the Dutch law of October 26th, I889, takes the same course, but the remark of De Lapradelle leads me to suppose that it does.

There is evidence, therefore, that the ten-mile limit for bays which has been adopted in international conventions is making headway also as a national limit for fishery purposes among certain States which do not possess a coastline of great incurvations. There is, however, little likelihood that it will find general acceptance among States with a coastline of different configuration. If, for instance, the eastern coast of the British Isles had been as serrated

50. Clunet, Journal de Droit Int. Priz'é, XIII. 126; See State Papers (Great Britain) Vol. Ixxix, p. 232, for the Frencl Decree delimiting, under this law, the bays in Algeria in which exclusive fishery rights are claimed for French nationals.

51. De Lapradelle, La Mer Territorialc, p. 45. 
as the west coast of Scotland, Great Britain, one may be sure, would not have agreed to the conventional delimitation of the German Ocean by the North Sea Convention.

In Great Britain attention has been drawn to this subject by the extensive claim to territorial jurisdiction over the Moray Firth, which the High Court of Justiciary in Edinburgh in the case of Mortensen v. Peters, ${ }^{52}$ declared to have been made by the Herring Fisheries (Scotland) Act of I889. Although, according to the court, the claim was asserted only for certain specified purposes, yet it appears to be inconsistent, not only with the limits of territorial waters in the North Sea, as defined by and acquiesced in by Great Britain in the North Sea Convention of I882, but also with a provision in a subsequent Statute of the British Parliament, the Herring Fisheries Amendment Act, 1895, to which I shall afterwards refer. It was only indirectly that an international issue was raised in the case, for the court considered that it had to deal purely with a question of construction arising on a clause in an Imperial Statute. But at least indirectly there was an international bearing, since the question at issue was whether a Statute creating an offence was binding on non-British subjects in what, but for previous statutory enactments, would undoubtedly have been held to be the high seas. The circumstances of the case were briefly these:-

The Danish master of the steam-trawler Niobe, registered in Sandefjord, Norway, was tried and convicted at the Sheriff Court, Dornoch (Cromartyshire), of having committed an offence under the Sea Fisheries Acts and Herring Fisheries (Scotland) Act, inasmuch as he had used at a place in the Moray Firth, five miles or thereby east by north from Lossiemouth, the method of otter-trawling which, by a by-law of the Scottish Fishery Board, is a method prohibited under penalty throughout the entire Moray Firth within a line drawn from Duncansby Head, in Caithness-shire, to Rattray Point, in Aberdeenshire. At the instance of the master, the case came on appeal before the High Court of Justiciary in Edinburgh, where it was elaborately argued before a full Bench, composed of twelve of the thirteen judges who form the Scots Supreme Court. The appellant's case-was that the alleged offence, having been committed on a foreign vessel at a spot more than three miles from lowwater mark on the Scottish coasts, was not cognizable by the Scots Court. Being a foreigner, he was not bound by a British Statute creating an offence in what was otherwise the high seas. These contentions were overruled by the court in a unanimous judgment by which the conviction was upheld. 
For a proper understanding of the point at issue, it is necessary to give some account of the geographical features of the Moray Firth, and of the British Fishery Legislation affecting Scotland, on the construction of which the court had to give its opinion.

(I) The Moray Firth proper is the most important of the arms ${ }^{\text {ts }}$ of the sea running in a southwesterly direction into the mainland of Scotland on its northeast coast. So far as it can be said to have headlands, these are formed on the one hand by Tarbet Ness (in Cromartyshire), which divides it from the smaller Dornoch Firth, and on the other by Burgh Head, a headland on the northwest coast of Elgin. The distance between these headlands is about fifteen miles, and the total extent of the Firth from that entrance to the mouth of the Beauly Firth, into which it merges at its upper end, is about thirty-one miles. This is the Moray Firth as it is usually designated on standard atlases and on the charts issued by the British Admiralty. But the area of water in question in Mortensen $v$. Peters was immensely larger, including the Moray, Cromarty, and Dornoch Firths, and extending seaward to a limit which had been laid down by a by-law of the Fishery Board for Scotland under powers delegated from Parliament.

This seaward limit can be readily appreciated on reference to a large scale map of Scotland, for it will then be seen that a straight line drawn in a southeasterly direction from Duncansby Head ${ }^{\text {s }}$ (the extreme northeast point on the mainland of Scotland, Caithness-shire) to Rattray Point, ${ }^{\text {ss }}$ on the east coast of Aberdeenshire (north of the seaport town of Peterhead), encloses a stretch of water forming, roughly, an equilateral triangle, its base being on the north coast-line of the counties of Aberdeen, Banff, and Elgin. The line between Duncansby Head and Rattray Point represents a distance of some eighty geographical miles, and the area enclosed by it to the westward is close on two thousand square geographical miles. Now it is this immense area of water which the High Court of Justiciary, interpreting a clause in an Act of Parliament, has declared to be (at least for certain purposes) within the territorial jurisdiction of Great Britain. It is plain, from the map, that the

53. The others are the Cromarty Firth, an entirely land-locked bay, lying to the northwest, with its entrance in the Moray Firth; and the Dornoch Firth, a true bay, lying to the north, and separated from the Moray Firth by Tarbet Ness.

54. Approximately in longitude 30 degrees, 59 minutes west of Greenwich, latitude 58 degrees, 38 minutes north.

55. Approximately in longitude 2 degrees west of Greenwich, latitude 57 degrees, 27 minutes, 30 seconds north. 
waters to the west of this line enter a coast-line of peculiar configuration, which only by stretching language can be called a bay. They include, as we have seen, two smaller areas of water, to which the term is not inappropriate, viz., at the western end of the triangle, the Moray Firth proper and the Dornoch Firth. But the headlands between which the line is drawn cannot reasonably be called the entrance to the statutory Moray Firth. Duncansby Head is simply the point at which the coast-line, after trending to the northwest, turns sharply to the west. Rattray Head, so far from being a headland in this connection, is actually to the south of Kinnaird Head, which, on the principle underlying the choice of Duncansby Head, might serve as the western headland to the bay. It happens, however, to be the first land which an imaginary line drawn southeast half east from Duncansby Head would touch on the Aberdeen coast. The waters ${ }^{58}$ enclosed by this line are not then properly comparable with those of any of the bays mentioned at an earlier part of this paper, e. g., Cancale Bay, Bay of Conception, or Delaware Bay. They bear most resemblance to the Bristol Channel, of which a description has already been given.

Let me now refer to the Fishery Legislation ${ }^{57}$ leading up to the Acts which the Court was called upon to construe.

The first definition of the coasts of Scotland is given in the Herring Fishery (Scotland) Act, 1867 (30 and 3 r Vic., c. 52), Section II of which provides that this expression, as used in the Act, "shall mean and include all bays, estuaries, and arms of the sea, and all tidal waters within three miles from the mainland or adjacent islands."

No innovation in the definition of Scottish territorial waters was made by the next Act, the Sea Fisheries Act, 1883 ( 46 and 47 Vic., c. 22), which, as regards Great Britain, carried into effect the pro-

56. And their extent has not escaped even judicial comment, for in ap earlier case before the same court (in which no question of the right of forcigners arose), the statutory Moray Firth was referred to "as a very extensive space . . . which includes the Moray Firth, but extends very much beyond what can properly be considered as a firth, and includes part of the ocean at a great distance from the shore," per Lord Kincairney in Green $\boldsymbol{v}$. Leith, 23 Court of Session Reports, 1896, 4th series, vol. xxiii., Justiciary Cases, p. 5o, at p. 54; and, again, "as a part of the sea of vast extent, and extending far out into the practically open sea for a considerable number of miles." Per Lord Justice Clerk Kingsburgh, Wilson v. Rust, loc. cit., p. 56 at p. 65.

57. These Acts may be conveniently referred to in the Manual of the Sea Fisheries (Scotland) Acts and Statutory By-laws, issued by the Fishery Board for Scotland, 1901, C. .D. 428. Price Is. 2d. 
visions of the North Sea Convention, I882. By this Statute certain things were declared (Section 4) to be offences "within the exclusive fishery limits of the British Islands," and these limits were defined (Section 28) in general terms to mean "that portion of the seas surrounding the British Islands, within which Her Majesty's subjects have by international law the exclusive right of fishing, and where such portion is defined by the terms of any convention, treaty, or arrangement for the time being in force between Her Majesty and any foreign State, includes, as regards the sea fishingboats and officers and subjects of that State, the portion so defined." In this Act, therefore, there was nothing out of which a claim to jurisdiction in territorial waters could be made save on the principle of international law, or by the terms of convention.

The next Act-the Sea Fisheries (Scotland) Amendment Act, I885-conferred important powers on the Fishery Board of Scotland. It empowered that body to issue by-laws (for the validity of which certain formalities and procedure were prescribed) to restrict or prohibit any method of sea-fishing in any part of the sea adjoining Scotland, and within the exclusive fishery limits of the British Islands, where such mode of fishing was, in the opinion of the Board, injurious to any kind of sea-fishing within such port. It was provided that the Board might make similar restrictions, or prohibitions, to enable it to make experiments. As this Act was to be read and construed along with that of 1883 , no alteration was made by it in the definition of the exclusive fishery limits of the British Islands.

In I889, however, an Act was passed which, at least in one particular, legislated for waters outside the exclusive fishery limits, as defined by the previous Statute. This was the Herring Fishery (Scotland) Act, I889 ( 52 and 53 Vic., c. 23), which had been passed at the instance of the line fishermen to protect them against the damage which was believed to be caused by the steam-trawlers. The Act contained a general prohibition against beam or otter-trawling, not only within three miles of low-water mark of any part of the coast of Scotland, but also in a list of waters which was specified in a schedule to the Act, save only between such points on the coast, or within such other defined areas as might from time to time be permitted by by-laws of the Scottish Fishery Board. The Board was therefore empowered to open parts of the waters which by the general prohibition were closed.

The schedule specifies waters which, for the most part, are on the west coast of Scotland, but at the end enumerates also certain 
firths and bays on the east coast. Among them is the upper part of Moray Firth.

This Act also contains in Section 7 the explicit provision with regard to the Moray Firth, on which the case under discussion turned. It runs as follows:-

(I) The Fishery Board may, by by-law or by-laws, direct that the methods of fishing known as beam-trawling and otter-trawling shall not be used within a line drawn from Duncansby Head, in Caithness, to Rattray Point, in Aberdeenshire, in any area or areas to be defined in such by-law, and may from time to time make, alter, and revoke, by-lazes for the purposes of this section, but no such by-law shall be of any validity until it has been confirmed by the Secretary for Scotland."

In 1892 the Fishery Board exercised the powers conferred on it by this section, and on 27 th September issued a by-law (No. Io) which was approved by the Secretary for Scotland on 22nd November, and by which the entire area, as defined in the section, was closed to beam or trawl fishermen.

The validity of this by-law was challenged in 1896 in the case of Green v. Leith, above referred to, on the ground that the Fishery Board was entitled to close only one area or more within the specified limit, and could not, therefore, prohibit trawling within the whole of the waters enclosed by the line between Duncansby Head and Rattray Point. This view was upheld by the Court of Justiciary when that case came before them on appeal, and a conviction obtained against a British trawler for an offence obtained under this by-law was quashed. But in the almost immediately subsequent case of Wilson $v$. Rust ${ }^{58}$ the same court reconsidered the validity of the by-law, and by a majority of five judges to two sustained it on the neat ground that the whole area was within, because none of it was without, the defined limit between the two headlands.

It was moreover pointed out that the word "area," as used in clause 7, was a neutral term, in no way implying an antithesis to the whole.

The effect, then, of this decision was to close the entire Moray Firth, as defined by the by-law, to trawling vessels registered in . Great Britain. To escape the restriction thus imposed, it is understood that the British owners of such vessels caused them to be registered in foreign countries, e. g., in Norway, in the belief that to vessels flying a foreign flag the restriction would not apply. This

58. February 27th, I896, 23 Court of Session Reports, 4th series (Justiciary Cases), p. 56. 
expedient proved successful, for until recently the Scottish Law Officers of the Crown held the opinion that the by-law could not be enforced against foreigners. Owing to the agitation caused by the British fishermen, who were chagrined to find that the waters from which they were themselves excluded were becoming a close preserve for foreign trawlers, the whole question was reconsidered, and in I9O4 a prosecution was raised against a foreigner, Olsen, the Norwegian master of the steam-trawler Catalonia, registered in Stavanger, Norway, for fishing by the prohibited method within the Dornoch Firth, at a point four miles southeast from Brora Point, contrary to By-law No. 2 of the Fishery Board, by which beam or otter-trawling at the place in question was prohibited. In the Sheriff Court of Dornoch the judge sustained Olsen's plea of no jurisdiction, based on the averment that the Catalonia, being registered in Norway, and Norway not being one of the Powers signatory to the North Sea Convention of 6th May, 1882, the master was not subject to the jurisdiction of Dornoch Sheriff Court. Under reservation of this plea the alleged offence was proved, but on an appeal at the instance of the Procurator-Fiscal the High Court of Justiciary sustained the jurisdiction of the Scots Court.

The judges held that the prohibition in Section 6 of the Herring Fishery (Scotland) Act I889, being quite general in its terms, applied equally to British subjects and foreigners, and that it was not for the courts to draw a distinction which Parliament had not seen fit to make. Lord Kyllachy was unable to see that any question of jurisdiction in territorial waters arose in the case, since the locus of the alleged offence was "well within the three-mile limit as generally interpreted, and particularly within the definition of that limit expressed ( $I$ think in entire consonance with international law) by Article 2 of the International Convention of $1882 . " 38$ The view of the court, therefore, was that Parliament had not exceeded any rule of international law by enacting a prohibition for the Dornoch Firth, which was a bay less than ten miles wide at the entrance, as defined by Section 2 of the North Sea Convention, and that the prohibition must apply to any person, whether subject or alien, within that bay, or within three miles seaward of the line connecting the headlands.

But in the next case, Mortensen $v$. Petcrs, the facts of which I have already stated, it was impossible to apply to the locus of the offence the rules of the North Sea Convention as to territorial

59. Peters :- Olsen, 7 Court of Session Repurts, 5th series (Justiciary Cases), p. 86 at p. 93 . 
waters. The place mentioned in the complaint is "five miles east by north from Lossiemouth" (a fishing village on the coast of Elgin). It was therefore outside the three-mile limit, measured from lowwater mark. Moreover, Lossiemouth is about ten miles to the east of Burgh Head, the headland on the Elgin coast forming the east entrance to the Moray Firth proper. But as the place was undoubtedy within a line drawn between Duncansby Head and Rattray Point, the case raised in the clearest way the question whether a prohibition enacted by Parliament applied to foreigners when within this area.

The argument for the appellant was based on the fundamental proposition that as the offence in question was created by municipal statute, it conferred jurisdiction only over British subjects and over foreigners within British territory. A prohibition against an act committed by any person meant "any person over whom the courts have jurisdiction." Our legislation is primarily territorial. It can in no case apply to foreigners outside British territory. Now the appellant was a foreigner, and it was submitted that he was not within British territorial waters when he was alleged to have contravened the by-law. By international law territorial jurisdiction ends at the three-mile limit, with the exception of bays intra fauces terre. ${ }^{00}$ There was no case in which a bay eighty miles wide has been held to be intra fauces terre. So far as any width is laid down as a limit the maximum is ten miles. Intra fauces terra implies something narrow-a land-locked bay such as can be defended from the shore. The Moray Firth, as defined by the by-law, does not satisfy the requirements of any of the writers as to intra fauces terre. There was no evidence that these waters have ever before been claimed as territorial, and, of course, no evidence that they had become so by acquiescence in that claim. In the North Sea Convention the North Sea is defined so as to include the Moray Firth, and the Convention admits that the waters therein dealt with are outside territorial limits. If the appellant here had been a subject of a power signatory to that Convention, and were claiming his rights under the Convention, the court would not construe the Statute so as to make it at variance with the Convention. The court could not construe it differently according to the nationality of the accused. It was not the law of Scotland that all waters within a line drawn from headland to headland are territorial. All that Stair ${ }^{61}$ says is that bays are capable of being declared territorial.

60. Lord Advocate v. Clyde Navigation Trustees, I891, Court of Session Reports, 4 th series, p. I74.

6r. James Dalrymple, Viscount Stair (1619-1695), was president of the Court of Session I6 -167I. His Institutes of the Law of Scotland, published 
For the Crown, on the other hand, it was argued that in the construction of the Statute there was no room for the presumption as to the exclusion of foreigners, inasmuch as it was clear and unambiguous in its terms, and related to an area specified and defined.

5.-To return to the several kinds of Real Rights, the first is that of Community which all men have of things which cannot be appropriate. . . . Thirdly, the vast ocean is common to all mankind, as to Navigation and Fishing, which are the only uses thereof, because it is not capable of bounds; but when the sea is enclosed in Bays, Creeks, or otherwise is capable of bounds or meeths as within the bounds of such lands or within view of such shores, there it may become proper, but with the reservation of passage for commerce as in the land.

The presumption was important only where the territory affected was undoubtedly not British. Where it was clearly or even in dubio British, the presumption did not apply. The appellant's argument from the limits of the North Sea as given in the Convention failed because those limits were agreed to only for the purposes of that Statute which were quite different from those of the by-law under discussion. Further, the Moray Firth is part of British territorial waters on the principle that all waters are territorial which are included within a line drawn from headland to headland. It is not a valid objection that the application of the rule here included a great amount of water. The only limit on the assertion of territorial rights is that no more is to be claimed than is reasonably necessary for the protection of the country's interests. Finally, even if the Moray Firth is not for all purposes territorial, Great Britain may make police regulations with regard to it in order to regulate the fishings.

The leading opinion of the High Court of Justiciary was delivered by the Lord Justice General (Lord Dunedin), who treated the question before the court as one purely of construction. The court, he said, had nothing to do with the question of whether the legislature had or had not done what foreign powers might consider a usurpation in a question with them. They had merely to give effect to a Statute of the British Parliament. The argument for the appellant as to the presumption against Statutes creating offences applying to foreigners was not conclusive, because the presumption might be redargued (rebutted). The question was whether it had been redargued on this occasion. In favor of an affirmative view was the strong inference to be derived from the terms of the prohibition

in $168 \mathrm{I}$, was the first treatise on the Law of Scotland, and is still of the highest authority. 4th edition, 1826 (ed. Brodie). The passage referred to is from Book II, Title I, "Rights Real or Dominion, wherein of Community, Possession and Property." 
in question. It was not an absolute prohibition against doing a certain thing, but a prohibition against doing it at a certain place.

"Now." he went on to say, "when a legislature using words of admitted generality, 'it shall not be lawful,' etc., 'for persons who,' etc., conditions an offence by territorial limits it creates, I think, a very strong inference that it is for the purposes specified assuming a right to legislate for that territory against all persons whomsoever. This inference seems to me still further strengthened when it is obvious that the remedy to the mischief sought to be obtained by the prohibition would be either defeated or rendered less effective if all persons whomsoever were not affected by the enactment. It is obvious that the latter consideration applies to the present case. Whatever may be the view of anyone as to the propriety or expediency of stopping trawling, the enactment shows on the face of it that it contemplates such stopping, and it would be most clearly ineffective to debar trawling by the British subjects while subjects of other nations were allowed so to fish."

His lordship next dealt with the argument that the locus of the occurrence in question was not touched by the Statute in so much as international law had formerly fixed it to be beyond the limits of territorial sovereignty. There was, he said, no such thing as a standard of international law extraneous to the domestic law of a kingdom to which an appeal may be made. "International law, so far as this court is concerned, is the body of doctrine regarding the international rights and duties of States which has been adopted and made part of the law of Scotland." It was, therefore, relevant to inquire whether the locus in this case was beyond the limits within which the British legislature might enact a prohibition directed against all the world for the purpose of regulating methods of fishing. That within the three-mile limit the territorial sovereignty would be sufficient to cover any such legislation as the present, was not proof of the counter proposition that outside that limit no such result could be looked for. Moreover, the locus was admittedly within the bay known as the Moray Firth, which the Crown said was intra fauces terra. Although there was no exact definition of this phrase, his lordship thought that three points might be referred to as going far to show that the locus here might be considered as lying intra fauces terre. He quoted the passage already cited from Stair to show that according to the law of Scotland it might so be considered. Moreover, the Statute under discussion shows that claims were put forward to legislate in other places far beyond the three-mile limit, e. g., the Firth of Clyde near its mouth; and, lastly, the decided cases of jurisdiction in wide bays supported the same conclusion.

"It seems to me, therefore," he said. in conclusion, "without laying down the proposition that the Moray Firth is for every purpose within the terri- 
torial sovereignty, it can at least be clearly said that the appellant cannot make out his proposition that it is inconceivable that the British legislature should attempt for fishery purposes to legislate against all and sundry in such a place, and if that be so then I revert to the consideration already stated, which as a matter of construction makes me think that it did so legislate."

The argument from the terms of the North Sea Convention he considered to fail because that Convention did not deal with what was in dispute here, namely, a mode of fishing. The Act moreover created no privilege in favor of British subjects, which was in conflict with the Convention. Subjects and foreigners are ex hypothesi treated alike.

Lord Kyllachy, while admitting that on the point of construction there was always a certain presumption against the legislature of the country asserting or assuming the existence of territorial jurisdiction going clearly beyond limits established by the common consent of nations, pointed out that this presumption might be redargued for the purposes. Express words would of course be conclusive, and so would plain implication. In the present case he considered the presumption to be redargued by the unlimited and unqualified terms of the prohibition applying to a specified area, and further by the consideration that the plain object of the enactment would have been defeated if the prohibition were not construed to apply also to foreigners.

"Accordingly," he said, "it would be, I think, easier to suppose that the legislature had reached even an erroneous conclusion as to the extent of its jurisdiction, and had legislated accordingly, than that it had resolved deliberately to impose a futile restriction upon its own countrymen, and at the same time to create a hurtful monopoly in favor of foreigners."

He further pointed out that the presumption had never been applied except when the excess of jurisdiction was clear. The whole ratio of the presumption fell if it appeared that the area which was in controversy was at best only in the position of debatable ground, being in effect within a category as to which different nations had always taken more or less different views, and maintained different conclusions. On the question of international law, his lordship held that no evidence of any recognized and established rule on the territoriality of wide bays had been adduced.

When one bears in mind that the court was construing an Act of Parliament, it is difficult to see how in accordance with the rules of law prevailing in Great Britain it could have reached a different conclusion, for undoubtedly it is not the business of a British Court to decide whether an Imperial Statute does or does not contravene a 
rule of international law. Whether in a question involving not statutory but common law it would have applied the dicta frequently expressed in earlier English and American cases, that international law is part of the law of the land, is a question which one must reserve until the case arises. To international lawyers the interest of this case lies less in the decision than in the legislation on which it turned. And here one cannot help feeling that the British Parliament, without perhaps being fully aware of what it was doing, has made, in reference to the Moray Firth, a claim to jurisdiction to which there is almost no parallel. The nearest claim is that made by Russia for purposes of war and neutrality over the White Sea, whose headlands are more than sixty miles apart, but other States are not particularly concerned with claims which a neighbor may make over waters within the Arctic Circle.

That this claim to jurisdiction over the Moray Firth was not made by Parliament in virtue of a settled principle in regard to wide bays is clearly shown by the Herring Fisheries Regulation (Scotland) Act of 1895 , in which Parliament proved itself much more chary in legislating, even for the purpose of fishery regulations, over areas of the sea at a distance from the British coast. This Act by Section ro empowers the Fishery Board to issue fishery regulations which shall be operative within thirteen miles of the Scottish coast, but for their validity it lays down strict conditions on a principle for which Mr. Barclay, at the meeting of the Institute of International Law at Paris, endeavored, without success, to obtain recognition. As an addition to Article 2 of the Paris Resolutions he proposed the following amendment:- "Dans le cas où un état voudrait soumettre la pêche à des réglements quelconques jusqu'à une distance plus grande que six milles de la côte, il faudrait l'assentiment des intéressés." This proposal was rejected. It was thought to be dangerous, as it might empower two States to put their heads together and establish all the sea virtually a mare clausum. Moreover, "intéressés" was indefinite. All peoples are "interested" in the freedom of the seas.

The Scotch Act, however, adopts this principle. It entitles the Fishery Board by by-law to direct that the methods of fishing known as beam-trawling and otter-trawling shall not be used in any area or areas under the jurisdiction of Her Majesty within thirteen miles of the Scottish coast to be defined in such by-law. The

62. De Lapradelle, La Mer Territoriale, p. 56 , erroneously gives the distance as thirty miles, and omits all mention of the conditions on which the validity of the by-law is made to depend. 
waters opposite any part of the coasts of England, Ireland, and the Isle of Man within thirteen miles thereof are expressly excepted. The Act therefore relates purely to Scotland. As a condition to the validity of the by-law the Secretary of Scotland must hold a local inquiry in the district adjoining the part of the sea to be included in the by-law, at which inquiry all persons interested shall be heard, whether resident in the district or not, and notice of such enquiry shall be sent to all Committees of sea fishery districts in the United Kingdom. It is further provided that no area of sea within the said limit of thirteen miles shall be deemed to be under the jurisdiction of Her Majesty for the purposes of this section unless the powers conferred thereby shall have been accepted as binding upon iheir own subjects with respect to such area by all the States signatory to the North Sea Convention, I882.

It seems clear that but for Clause 7 of the Herring Fishery (Scotland) Act, 1889, the Fishery Board could not subsequently to this Act prohibit beam or otter-trawling in the Moray Firth even up to thirteen miles of the Scottish coast without satisfying the conditions of enquiry by the Secretary of Scotland, and assent on the part of the signatories to the North Sea Convention as provided in the Act. It would, therefore, seem that since the passing of the Act of 1889 and before the Act of 1895 the mind of Parliament had changed with regard to the extent of its jurisdiction in Scottish waters.

A. H. Charteris.*

*Lecturer on Public International and International Private Law in the University of Glasgow, Scotland. 